Impact of sow and litter characteristics on colostrum yield, time for onset of lactation, and milk yield of sows

Vadmand, Camilla Nielsen; Larsen, Uffe Krogh; Hansen, Christian Fink; Theil, P. K.

Published in:

Journal of Animal Science

DOI:

10.2527/jas.2014-8659

Publication date:

2015

Document version

Early version, also known as pre-print

Citation for published version (APA):

Vadmand, C. N., Larsen, U. K., Hansen, C. F., \& Theil, P. K. (2015). Impact of sow and litter characteristics on colostrum yield, time for onset of lactation, and milk yield of sows. Journal of Animal Science, 93(5), $2488-2500$. https://doi.org/10.2527/jas.2014-8659 


\title{
Impact of sow and litter characteristics on colostrum yield, time for onset of lactation, and milk yield of sows
}

\author{
C. N. Vadmand, ${ }^{\star} \dagger$ U. Krogh, ${ }^{*}$ C. F. Hansen, $\dagger$ and P. K. Theil ${ }^{* 1}$ \\ *Department of Animal Science, Aarhus University, \\ Research Center Foulum, DK-8830 Tjele, Danmark; †ंDepartment of Large Animal Science, \\ Faculty of Health and Medical Science, University of Copenhagen, DK-1870 Frederiksberg C, Denmark
}

\begin{abstract}
The aim of the present study was to estimate the concurrent impact of sow and litter characteristics on sow productivity. Sow productivity was defined as colostrum yield (CY), onset of lactation (the time point when milk secretion increased steeply, approximately $31 \mathrm{~h}$ postpartum), transition milk yield (MY; 36-60 $\mathrm{h}$ postpartum), and the mean MY in wk 1 to 4 of lactation. Therefore, the study investigated how factors related with sow nutrition, litter characteristics, farrowing characteristics, and composition of mammary secreta affected sow productivity. Data obtained from 5 previous sow experiments were used. The variables describing sow productivity were all defined as dependent variables and Pearson coefficient of correlation was used to examine relations among dependent variables. The results showed that $\mathrm{CY}$ was positively correlated with transition $\mathrm{MY}$ and $\mathrm{MY}$ in wk 1 and 2 of lactation $(P<0.05)$, and time for onset of lactation was positively correlated with transition MY $(P<$ 0.05 ) but negatively correlated with MY in wk 1,2 , and 4 of lactation $(P<0.05)$. Multivariate regression
\end{abstract}

analyses with a backward elimination approach were performed for each dependent variable to investigate relations with characteristics of sow nutrition, litter size, farrowing, and composition of mammary secreta (independent variables). Litter size was positively related with both $\mathrm{CY}$ and $\mathrm{MY}$ in wk 1 to $4(P<0.001)$. Milk protein concentration was negatively correlated with MY in all $4 \mathrm{wk}(P<0.01)$, which indicated that high yielding sows were unable to maintain milk protein synthesis during lactation. Additionally, mean intake of ME prepartum $(P<0.05)$ was included in the regression model for transition $\mathrm{MY}$ and the $\mathrm{BW}$ of the sow on $\mathrm{d} 3$ was included in the regression model for MY in wk $1(P<0.05)$. Except litter equlization, none of the observed independent variables were related with time for onset of lactation. In conclusion, when maximizing sow productivity in the future, it may be rewarding to pay attention to sow productivity in the colostrum period and around time for onset of lactation, and special attention should be given to dietary supplies of protein and essential AA.

Key words: mammary secreta, milk yield, onset of lactation, protein, transition milk

\section{INTRODUCTION}

Sufficient intake of mammary secreta is essential for piglet survival and growth from birth until weaning (Noblet and Etienne, 1989; Harrell et al., 1993; Hales et al., 2013). Newborn piglets are highly dependent on the energy-rich colostrum because they are born with limited glycogen depots (Theil et al., 2011). A gap oc-

\footnotetext{
${ }^{1}$ Corresponding author: Peter.Theil@agrsci.dk

Received October 27, 2014.

Accepted March 12, 2015.
}

curs in the energy intake of newborn piglet during the late phase of the colostrum period and until the onset of lactation approximately $31 \mathrm{~h}$ postpartum (Theil et al., 2014b). The first milk secreted at onset of lactation is related to great changes in nutrient composition, especially the increase in the concentration of milk fat (Klobasa et al., 1987), and the milk secreted from onset of lactation to $60 \mathrm{~h}$ postpartum may be defined as transition milk yield (MY). After it is established, mature milk is the main energy source for the piglets (Harrell et al., 1993). The piglets' intake of colostrum and milk are dependent on the production of the sow 
(Le Dividich et al., 2005). The ability to produce colostrum and milk is highly variable among sows (Quesnel, 2011; Hansen et al., 2012b), which is relatively unexplained but probably influenced by a number of factors such as nutrition, genetics, management, environment, health, and characteristics of farrowing and the litter (King, 2000; Farmer and Quesnel, 2009).

The objective of this study was first to investigate possible correlations within sow productivity defined as colostrum yield (CY), onset of lactation, transition MY, and mean weekly MY throughout lactation. Second, the aim was to investigate the impact of factors related to characteristics of nutrition, litter, farrowing, and mammary secreta on sow productivity. The outcome will contribute to increase knowledge on sow lactation and highlight opportunities to improve sow productivity in the future, for the benefit of piglet survival and growth.

\section{MATERIALS AND METHODS}

Animal housing and rearing were in compliance with Danish laws and regulations for the humane care and use of animals in research (The Danish Ministry of Justice). The Danish Animal Experimentation Inspectorate approved the study protocols and supervised the experiment. The health of the animals was monitored, and no illnesses were observed. Data was obtained from 5 independent experiments (Exp. 1 through 5), which were conducted at research Centre Foulum, Tjele, Denmark, between 2007 and 2013 using a total of 132 sows (Danish Landrace $\times$ Yorkshire) that had been artificially inseminated with Duroc semen. The 5 experiments investigated effects of feed composition on sow and piglet performance, whereby parameters concerning sow and litter performance were collected. Eight sows with an unusually low feed intake during late gestation $(<1.7 \mathrm{~kg} / \mathrm{d})$, with short gestation length $(<111 \mathrm{~d})$, or with numerous stillborn piglets ( $>7$ piglets) were excluded from this study due to suspicion of disease. Furthermore, 3 sows with a litter size below 9 live-born piglets were excluded to ensure the sows represented modern highly prolific sows.

\section{Description of Study Population in the Conducted Experiments}

Therefore, the 5 experiments represented 121 sows and total 2,044 born piglets including both live-born and stillborn piglets. First to fifth parity sows-but predominantly second parity sows - were used in the experiments $(n=99)$. A gestation diet was fed from mating to about $1 \mathrm{wk}$ before the expected farrowing, when the gestation diet was replaced with a lactation diet. The sows were fed 2 (Exp. 1) or 3 daily meals (Exp. 2 to
5). All diets were mainly based on barley, wheat, and soybean meal as the main ingredients but the feed composition varied between experiments and among treatments. The feed compositions used in Exp. 1, Exp. 2, Exp. 3, and Exp. 4 are described in details by Hansen et al. (2012a), Krogh et al. (2015), Krogh et al. (2012), and Flummer et al. (2012), respectively, whereas Exp. 5 is an ongoing experiment in which sows are fed with or without supplementary Arg (Krogh, U., A.C. Storm, and P. K. Theil, Department of Animal Science, Aarhus University, unpublished data). All sows in late gestation and early lactation were restrictively fed with a reduced feed intake around farrowing. After farrowing, the feed intake was gradually increased until peak lactation when Danish sows were fed semi-ad libitum (Theil et al., 2012), that is, sows were daily supplied with up until 9 feed units (equivalent to approximately $8.3 \mathrm{~kg}$ of feed). The amount of provided feed was registered and except for Exp. 3, feed residues were collected and weighed on a daily basis for each sow. Moreover, the sows and piglets had free access to water. Approximately $1 \mathrm{wk}$ before expected farrowing, sows were placed in individual farrowing crates equipped with an infrared lamp to establish a warm microclimate for the piglets. The $\mathrm{BW}$ of the sows $\left(\mathbf{B W}_{\text {sow }}\right)$ was determined on $\mathrm{d}-8,3$, and 28 , where $\mathrm{d} 0$ represented the day of farrowing. Back fat depth was measured on $\mathrm{d}-8$ and 28 by ultrasound using a $7.5 \mathrm{-MHz}$ Linear Intraoperative Probe ALOKA (UST-5561/7.5; Simonsen \& Weel, Vallensbaek Strand, Denmark), as described in detail by Hansen et al. (2012a).

All sows farrowed naturally; hence, no farrowing was induced. Birth assistance was provided only if birth interval exceeded $1.5 \mathrm{~h}$. The numbers of live-born and stillborn piglets in each litter were recorded along with the birth time of each piglet. Every newborn piglet was picked up from the crate before it reached the udder of the sow. The newborn piglet was dried with paper towels and ear tagged for individual identification, and the umbilical cord was shortened to approximately $15 \mathrm{~cm}$. Body weight of the piglet $\left(\mathbf{B W}_{\text {piglet }}\right)$ was then recorded and the piglet was returned to the crate and allowed to suckle colostrum. Litter equalization was performed no earlier than $24 \mathrm{~h}$ after parturition and with the same equalized litter size within the experiment (10 to 14 piglets/litter) The individual piglets were weighed at $12,24,30,36$, and $48 \mathrm{~h}$ after birth of first piglet and once every week during lactation. Time and $\mathrm{BW}_{\text {piglet }}$ were recorded for piglets that died during the experimental period. Sows and piglets were inspected daily to ensure health. The experiments ended on $\mathrm{d} 28$ when the piglets were weaned.

From each sow, a $50-\mathrm{mL}$ sample of colostrum was collected within $1 \mathrm{~h}$ after birth of first piglet and 300 to $400 \mathrm{~mL}$ milk was collected in each week of lactation (wk 1,2,3, and 4), of which $50 \mathrm{~mL}$ was stored for later 
analysis. Injection with oxytocin $(0.3 \mathrm{~mL}$ intravenously or $2.5 \mathrm{~mL}$ intramuscularly, $10 \mathrm{IU} / \mathrm{mL}$; Løvens Kemiske Fabrik, Ballerup, Denmark) was used to induce milk ejection when sampling during the lactating period. The milking procedure continued until milk let down ceased or until approximately $400 \mathrm{~mL}$ of milk was collected. All colostrum and milk samples were hand milked from up to 3 randomly chosen teats. The samples were stored at $-20^{\circ} \mathrm{C}$ until further analysis. Both colostrum and milk samples were analyzed for macrochemical composition of fat, protein, lactose, and DM using a MilkoScan FT2 instrument (Foss, Hillerød, Denmark).

\section{Colostrum Yield, Onset of Lactation, and Milk Yields}

The yield of the sows was divided into different phases, namely CY, transition MY, and MY in wk 1,2,3, and 4 (MY1, MY2, MY3, and MY4). Each of these yields was considered a dependent variable and separately analyzed. Additionally, onset of lactation, defined as the time point when milk production increased abruptly around 31 $\mathrm{h}$ postpartum, was chosen as dependent variable.

The CY was defined as the yield from 0 to $24 \mathrm{~h}$ after initiation of farrowing (Quesnel et al., 2013). The sum of colostrum intake estimated for all piglets within a litter was calculated to quantify the CY. Estimation of the colostrum intake for individual piglets was based on the following equation described by Theil et al. (2014a):

$$
\begin{aligned}
& \mathrm{CI}=-106+2.26 \times \mathrm{WG}+200 \times \mathrm{BWB}+0.111 \times \\
& \mathrm{D}-1,414 \times \mathrm{WG} / \mathrm{D}+0.0182 \times \mathrm{WG} / \mathrm{BWB},
\end{aligned}
$$

in which $\mathbf{C I}$ is colostrum intake (g), WG is weight gain of the individual piglet from birth to $24 \mathrm{~h}$ after first born piglet (g), BWB is BW of individual piglets at birth $(\mathrm{kg})$, and $\mathrm{D}$ is the duration of colostrum intake (min) for individual piglets (Theil et al., 2014a).

Onset of lactation was calculated using a broken

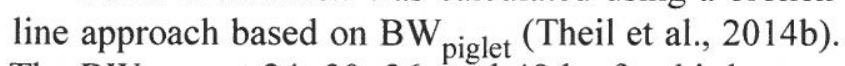
The $\mathrm{BW}_{\text {piglet }}$ at $24,30,36$, and $48 \mathrm{~h}$ after birth were used as indicators for milk intake and onset of lactation was shown by a sudden rapid increase in $\mathrm{BW}_{\text {piglet }}$ The broken line approach consisted of a plateau line $($ slope $=0)$ and an increased growth line with a slope $>$ 0 . The break point between the 2 lines represented the time for onset of lactation.

The transition MY was defined as the yield from 36 to $60 \mathrm{~h}$ after parturition. The sum of transient milk intake estimated for all piglets within a litter was calculated to quantify the transition MY. The equation for predicting the transition milk intake of piglets was adapted from Theil et al. (2002) and calculated by the following equation:

$$
\begin{aligned}
& \mathrm{TMI}_{36-60} \mathrm{~h}=226+1.168 \times \mathrm{WG}_{36-60} \mathrm{~h}+ \\
& 0.00425 \times \mathrm{WG}^{2}{ }_{36-60} \mathrm{~h},
\end{aligned}
$$

in which TMI is the transition milk intake (g) and WG is the weight gain of individual piglets $(\mathrm{g})$. The intercept of the regression model $(226 \mathrm{~g})$, which denotes the amount of milk required to maintain a constant $\mathrm{BW}$, was modified to fit the particular time period concerning transition milk.

The mean MY in wk 1,2,3, and 4 were predicted based on the model describing the lactation curve for sows developed by Hansen et al. (2012b). Mean litter size and mean litter gain (in $\mathrm{kg} / \mathrm{d}$ ) were recorded for each week of lactation and used as inputs to estimate the MY (in $\mathrm{kg} / \mathrm{d}$ ) from $\mathrm{d} 2$ to 28 of lactation. The daily MY were then used to calculate the mean MY in each of the 4 wk of lactation, denoted MY1, MY2, MY3, and MY4, respectively.

The CY, transition MY, MY1, MY2, MY3, and MY4 are expressed in kilograms per day and onset of lactation is expressed in hours from initiation of parturition. Means of the sow productivity are represented in Table 1 for each of the 5 experiments.

\section{Independent Variables}

In total, 79 variables were defined as independent variables. Most but not all of the independent variables were available in the 5 experiments included in this study and traits that were related with one or more of the dependent variables are shown in Tables 2 and 3 . The independent variables were categorized into 4 groups, namely, traits related with sow nutrition, litter characteristics, farrowing characteristics, and composition of mammary secreta.

Sow nutrition included the following variables: ADFI and mean daily intake of ME prepartum; mean daily intake of protein, fat, and AA (Lys, Thr, and Val) and $\mathrm{ADFI}$ during the lactating period; and $\mathrm{BW}_{\text {sow }}$, back fat thickness, and loss of $\mathrm{BW}_{\text {sow }}$ and back fat during lactation. The daily intake of ME prepartum was included as a variable, because the energy content of the feed varied between experiments and among treatments and because the energy supply to Danish sows is lowered on $\mathrm{d} 112$ of gestation, that is, $3 \mathrm{~d}$ before expected parturition (Theil et al., 2012). Because the period with low feed allotment varied among individual sows, it may influence the sow productivity. The ADFI and mean daily ME postpartum were determined from $d-7$ to -3 and from $\mathrm{d}-2$ to parturition (notice the gestation length is variable). Mean daily intake of feed, protein, fat, and AA (Lys, Thr, and Val) postpartum were determined for each week of lactation. The ADFI was obtained by subtracting feed residues from the amount of feed provided, whereas mean daily intake of fat, protein, $\mathrm{AA}$, and $\mathrm{ME}$ were determined by multiplying ADFI with the dietary 
Table 1. Descriptive statistic of sow productivity including colostrum yield (CY), onset of lactation transition milk yield (MY) and MY in wk 1, 2, 3, and 4 (MY1, MY2, MY3, and MY4) for the 5 included experiments

\begin{tabular}{|c|c|c|c|c|c|}
\hline & Exp. 1 & Exp. 2 & Exp. 3 & Exp. 4 & Exp. 5 \\
\hline Item & $\begin{array}{c}\text { Mean } \pm \mathrm{SD} \\
{[\text { minimum, maximum] }}\end{array}$ & $\begin{array}{c}\text { Mean } \pm \text { SD } \\
\text { [minimum, maximum] }\end{array}$ & $\begin{array}{c}\text { Mean } \pm \mathrm{SD} \\
{[\text { minimum, maximum] }}\end{array}$ & $\begin{array}{c}\text { Mean } \pm \text { SD } \\
\text { [minimum, maximum] }\end{array}$ & $\begin{array}{c}\text { Mean } \pm \text { SD } \\
{[\text { minimum, maximum] }}\end{array}$ \\
\hline $\bar{n}$ & 46 & 31 & 23 & 8 & 13 \\
\hline \multirow[t]{2}{*}{$\mathrm{CY}, \mathrm{kg} / \mathrm{d}$} & $5.49 \pm 1.22$ & $6.24 \pm 1.02$ & $5.87 \pm 0.74$ & $6.55 \pm 1.32$ & $6.67 \pm 0.91$ \\
\hline & {$[2.75,8.45]$} & {$[4.40,8.39]$} & {$[4.00,6.91]$} & {$[5.05,8.54]$} & {$[5.39,8.12]$} \\
\hline \multirow[t]{2}{*}{ Onset of lactation, $\mathrm{h}$} & - & $30.2 \pm 2.78$ & $32.0 \pm 4.15$ & $31.7 \pm 3.03$ & $29.8 \pm 4.48$ \\
\hline & - & {$[24.1,34.3]$} & {$[24.0,39.4]$} & {$[27.9,36.0]$} & {$[22.5,34.3]$} \\
\hline \multirow[t]{2}{*}{ Transition MY, kg/d } & - & $6.37 \pm 1.77$ & - & - & $7.69 \pm 2.27$ \\
\hline & - & {$[3.68,11.9]$} & - & - & {$[3.49,11.2]$} \\
\hline \multirow[t]{2}{*}{ MY $1, \mathrm{~kg} / \mathrm{d}$} & $7.92 \pm 0.52$ & $8.84 \pm 0.68$ & $8.37 \pm 0.69$ & $8.16 \pm 0.46$ & $9.28 \pm 0.39$ \\
\hline & {$[6.63,8.54]$} & {$[6.85,9.78]$} & {$[7.13,9.55]$} & {$[7.67,9.10]$} & {$[8.45,9.67]$} \\
\hline \multirow[t]{2}{*}{$\mathrm{MY} 2, \mathrm{~kg} / \mathrm{d}$} & $11.1 \pm 1.06$ & $12.9 \pm 1.52]$ & $11.3 \pm 1.41$ & $11.3 \pm 1.64$ & $13.8 \pm 1.27$ \\
\hline & {$[7.55,12.9]$} & {$[9.34,15.4]$} & {$[8.85,14,6]$} & {$[8.78,13.9]$} & {$[11.5,15.8]$} \\
\hline \multirow[t]{2}{*}{ MY3, kg/d } & $12.6 \pm 1.51$ & $13.3 \pm 2.43$ & $12.8 \pm 1.30$ & $12.7 \pm 1.76$ & $14.7 \pm 2.74$ \\
\hline & {$[9.21,15.2]$} & {$[8.43,18.3]$} & {$[10.2,15.0]$} & {$[10.2,15.4]$} & {$[9.05,18.8]$} \\
\hline \multirow[t]{2}{*}{$\mathrm{MY} 4, \mathrm{~kg} / \mathrm{d}$} & $12.5 \pm 1.78$ & $13.1 \pm 2.52$ & $12.5 \pm 1.32$ & $12.2 \pm 3.53$ & $14.2 \pm 2.82$ \\
\hline & {$[9.14,16.7]$} & {$[7.92,17.4]$} & {$[9.28,15.3]$} & {$[6.05,16.9]$} & {$[9.37,18.9]$} \\
\hline
\end{tabular}

nutrient. The loss of $\mathrm{BW}_{\text {sow }}$ was determined from $\mathrm{d}-8$ to 3 and from d 3 to 28 , and loss of back fat was determined from $\mathrm{d}-8$ to 28 . The loss of BW and back fat reflected the mobilization from body reserves, and the parameters should be interpreted as negative values representing loss of $\mathrm{BW}_{\text {sow }}$ or back fat and positive values representing gain of $\mathrm{BW}_{\text {sow }}$ or back fat. Means, $\mathrm{SD}$, and minimum and maximum values of the independent variables in relation to sow nutrition and that were positively or negatively related with the dependent variables are summarized in Table 2.

Litter characteristics included the number of total born, live-born, and stillborn piglets; litter size $24 \mathrm{~h}$ postpartum; and mean weekly litter size during lactation. Mean litter size was assessed on a weekly basis to account for piglets that died during lactation. Additionally, litter weight at birth was calculated as the sum of $\mathrm{BW}_{\text {piglet }}$ of piglets born alive in each litter. In the different analyses included in this study, the number of stillborn piglets was expressed as odds of stillbirth. Odds of stillbirth was calculated as the probability of being stillborn divided by the probability of being born alive.

Traits related to farrowing included gestation length, farrowing length, mean birth interval, colostrum availability, and colostrum removal. Colostrum availability was defined as the time used to hand milk a $50 \mathrm{~mL}$ colostrum sample from up to 3 random chosen teats when the first piglet was born. Colostrum removal was defined as the percentage of the total colostrum production $(0-24 \mathrm{~h})$ that was secreted within the first $12 \mathrm{~h}$ after initiation of parturition. The CY0-12 $\mathrm{h}$ was estimated as the sum of colostrum intake, which was predicted based on a modified version of the model for colostrum intake developed by Theil et al. (2014a):

$$
\begin{aligned}
& \mathrm{CI}_{0-12} \mathrm{~h}=-53+2.26 \times \mathrm{WG}_{0-12 \mathrm{~h}}+100 \times \mathrm{BWB} \\
& +0.111 \times \mathrm{D}_{0-12 \mathrm{~h}}-1,414 \times \mathrm{WG}_{0-12} \mathrm{~h} / \mathrm{D}_{0-12} \mathrm{~h} \times \\
& \mathrm{D}_{0-12 \mathrm{~h}} / \mathrm{D}_{0-24 \mathrm{~h}}+0.0182 \times \mathrm{WG}_{0-12 \mathrm{~h}} / \mathrm{BWB}, \quad[3]
\end{aligned}
$$

in which $\mathrm{CI}_{0-12} \mathrm{~h}$ is colostrum intake $(\mathrm{g})$ in the first half of the 24-h colostrum period, $W_{0-12} \mathrm{~h}$ is weight gain of individual piglets from birth to $12 \mathrm{~h}$ after first born piglet $(\mathrm{g}), \mathrm{BWB}$ is BW of individual piglets at birth $(\mathrm{kg})$, and D0-12 h and D0-24 h are durations of colostrum intake ( $\mathrm{min}$ ) within the 12 - or 24 -h period, respectively.

The independent variables related to the composition of mammary secreta were protein, fat, lactose, and DM concentration. The content of GE in colostrum and in the milk samples for the 4 wk of lactation were estimated from the equation described by Chwalibog (2006):

$$
\begin{aligned}
& \mathrm{GE}=0.0238 \times \text { protein }+0.0389 \times \text { fat }+ \\
& 0.0163 \times \text { lactose }
\end{aligned}
$$

in which GE is expressed in megajoules per $100 \mathrm{~g}$ and protein, fat, and lactose are expressed in grams per $100 \mathrm{~g}$ of mammary secreta.

Means, SD, and minimum and maximum values of the independent variables related to litter characteristics, farrowing characteristics, and composition of mammary secreta and that were positively or negatively correlated with the dependent variables are summarized in Table 3 for each of the 5 experiments. 
Table 2. Descriptive statistic of the independent variables ${ }^{1}$ associated with the sow nutrition in the 5 included experiments

\begin{tabular}{|c|c|c|c|c|c|}
\hline & Exp. 1 & Exp. 2 & Exp. 3 & Exp. 4 & Exp. 5 \\
\hline Item & $\begin{array}{c}\text { Mean } \pm \text { SD } \\
{[\text { minimum, maximum] }}\end{array}$ & $\begin{array}{c}\text { Mean } \pm \text { SD } \\
{[\text { minimum, maximum }]}\end{array}$ & $\begin{array}{c}\text { Mean } \pm \text { SD } \\
{[\text { minimum, maximum] }}\end{array}$ & $\begin{array}{c}\text { Mean } \pm \text { SD } \\
\text { minimum, maximum] }\end{array}$ & $\begin{array}{c}\text { Mean } \pm \text { SD } \\
\text { [minimum, maximum] }\end{array}$ \\
\hline \multirow[t]{2}{*}{ ADFI wk $1, \mathrm{~kg}$} & $4.36 \pm 0.36$ & $3.97 \pm 0.52$ & - & $3.88 \pm 0.14$ & $3.27 \pm 0.15$ \\
\hline & {$[3.74,5.57]$} & {$[3.20,5.24]$} & - & {$[3.73,4.13]$} & {$[3.06,3.61]$} \\
\hline \multirow[t]{2}{*}{ ADFI wk $2, \mathrm{~kg}$} & $6.62 \pm 0.44$ & $6.26 \pm 0.56$ & - & $7.06 \pm 0.32$ & $6.38 \pm 0.46$ \\
\hline & {$[5.60,7.43]$} & {$[5.05,7.22]$} & - & {$[6.62,7.43]$} & {$[5.17,7.11]$} \\
\hline \multirow[t]{2}{*}{ ADFI wk $3, \mathrm{~kg}$} & $7.85 \pm 0.62$ & $6.74 \pm 1.07$ & - & $6.99 \pm 0.52$ & $7.90 \pm 0.68$ \\
\hline & {$[6.00,8.71]$} & {$[4.42,8.37]$} & - & {$[6.64,8.00]$} & {$[6.11,8.52]$} \\
\hline \multirow[t]{2}{*}{ ADFI wk 4, kg } & $8.11 \pm 0.63$ & $7.10 \pm 0.91$ & - & $6.48 \pm 0.70$ & $7.81 \pm 0.65$ \\
\hline & {$[6.86,9.20]$} & {$[4.90,8.44]$} & - & {$[5.73,7.61]$} & {$[6.11,8.47]$} \\
\hline \multirow[t]{2}{*}{ Mean daily protein intake, ${ }^{1} \mathrm{~g}$} & $1,181 \pm 107$ & $825 \pm 103$ & - & $1,077 \pm 74.3$ & $941 \pm 68.3$ \\
\hline & {$[623,1,662]$} & {$[425,1,183]$} & - & {$[658,1,413]$} & {$[466,1,259]$} \\
\hline \multirow[t]{2}{*}{ Mean daily fat intake, ${ }^{1} \mathrm{~g}$} & $562 \pm 103$ & $373 \pm 66.0$ & - & $308 \pm 21.3$ & $302 \pm 23.8$ \\
\hline & {$[245,856]$} & {$[161,625]$} & - & {$[188,405]$} & {$[144,406]$} \\
\hline \multirow[t]{2}{*}{ Mean daily Lys intake, ${ }^{1} \mathrm{~g}$} & $60.1 \pm 6.67$ & $39.6 \pm 5.14$ & - & $51.5 \pm 3.55$ & $50.1 \pm 3.78$ \\
\hline & {$[30.3,86.7]$} & {$[20.6,60.9]$} & - & {$[31.4,67.5]$} & {$[23.7,67.8]$} \\
\hline \multirow[t]{2}{*}{ Mean daily Thr intake, ${ }^{1} \mathrm{~g}$} & $44.1 \pm 4.59$ & $27.7 \pm 3.14$ & - & $38.1 \pm 2.62$ & $33.8 \pm 2.55$ \\
\hline & {$[22.5,62.8]$} & {$[14.9,39.7]$} & - & {$[23.3,49.9]$} & {$[15.9,45.7]$} \\
\hline \multirow[t]{2}{*}{ Mean daily Val intake, ${ }^{1} \mathrm{~g}$} & $60.8 \pm 6.09$ & $33.3 \pm 3.83$ & - & $55.4 \pm 3.82$ & $43.9 \pm 3.34$ \\
\hline & {$[31.3,86.8]$} & {$[18.0,49.1]$} & - & {$[33.8,72.6]$} & {$[20.7,59.4]$} \\
\hline \multirow[t]{2}{*}{$\mathrm{BW}_{\text {sow }}{ }^{2} \mathrm{~d}-8, \mathrm{~kg}$} & $248 \pm 19.8$ & $280 \pm 23.3$ & - & $271 \pm 15.3$ & $290 \pm 27.9$ \\
\hline & {$[218,290]$} & {$[228,321]$} & - & {$[249,296]$} & {$[252,352]$} \\
\hline \multirow[t]{2}{*}{$\mathrm{BW}_{\text {sow }} \mathrm{d} 3, \mathrm{~kg}$} & - & $261 \pm 22.3$ & - & $244 \pm 14.3$ & $266 \pm 30.1$ \\
\hline & - & {$[202,301]$} & - & {$[225,272]$} & {$[232,335]$} \\
\hline \multirow[t]{2}{*}{$\mathrm{BW}_{\text {sow }} \mathrm{d} 28, \mathrm{~kg}$} & $228 \pm 19.5$ & $238 \pm 19.6$ & - & $223 \pm 18.1$ & $242 \pm 25.8$ \\
\hline & {$[191,272]$} & {$[182,287]$} & - & {$[201,243]$} & {$[216,299]$} \\
\hline \multirow[t]{2}{*}{ Back fat $\mathrm{d}-8, \mathrm{~mm}$} & $16.4 \pm 2.29$ & $23.4 \pm 7.50$ & $20.0 \pm 3.15$ & $17.3 \pm 2.10$ & $14.4 \pm 2.77$ \\
\hline & {$[9.60,23.0]$} & {$[14.2,41.0]$} & {$[12.8,25.8]$} & {$[15.3,21.3]$} & {$[10.2,18.8]$} \\
\hline \multirow[t]{2}{*}{ Back fat loss $\mathrm{d}-8$ to $28, \mathrm{~mm}$} & $-2.4 \pm 1.9$ & $-8.18 \pm 6.2$ & - & $-2.8 \pm 2.2$ & $-4.3 \pm 2.0$ \\
\hline & {$[-5.8,2.1]$} & {$[-22,3.3]$} & - & {$[-5.8,-0.5]$} & {$[-7.8,-1.7]$} \\
\hline
\end{tabular}

${ }^{1}$ Traits were measured weekly but here data represents mean for $4 \mathrm{wk}$ of lactation.

${ }^{2} \mathrm{BW}_{\text {sow }}=\mathrm{BW}$ of the sow.

\section{Statistical Analysis}

Statistical analyses were performed in SAS (version 9.3; SAS Inst. Inc., Cary, NC). Normality of the data and homoscedasticity was checked using standard procedures. Odds of stillbirth, birth interval, farrowing length, and colostrum availability were all skewed and consequently log transformed to achieve normal distribution. Onset of lactation for each sow was calculated by a broken-line analysis using the NLIN procedure of SAS to estimate the break point of BW gain of piglets. Colostrum yield, onset of lactation, transition MY, and mean weekly MY were defined as dependent variables. Relations between the dependent variables were evaluated by Pearson correlation coefficients using the CORR procedure of SAS. All independent variables were individually screened for association and collinearity with the dependent variables by use of PROC CORR. All independent variables that were significant at a $5 \%$ level associated with the dependent variables were offered to a multivariable model. The multivariable analysis was performed with a backward elimination strategy using PROC GLM. The independent variables had to be earlier in time, so the independent variable actually could affect the dependent variable. An exception was the $\mathrm{BW}_{\text {sow }}$ on $\mathrm{d} 3$, which was included in the analysis of $\mathrm{CY}$ because it closely reflects the $\mathrm{BW}_{\text {sow }}$ at parturition. In contrast, the recorded $\mathrm{BW}_{\text {sow }}$ before parturition includes weight of fetuses, placenta and uterine fluids, and membranes and hence does not reflect the variation in BW among individual sows. The experiment and treatments within experiments were included in each multivariate model to account for a possible effect of the different experiments and dietary treatments. Each regression model was validated by inspections of residuals. In general, the descriptive statistics were reported as mean $\pm \mathrm{SD}$ and minimum and maximum values for the dependent variables and the associated independent variables. Unless otherwise stated, significance was accepted at $P \leq 0.05$. 
Table 3. Descriptive statistic of the independent variables associated with litter size, farrowing, and colostrum and milk composition in the 5 included experiments

\begin{tabular}{|c|c|c|c|c|c|}
\hline & Exp. 1 & Exp. 2 & Exp. 3 & Exp. 4 & Exp. 5 \\
\hline Item & $\begin{array}{c}\text { Mean } \pm \text { SD } \\
{[\text { minimum, maximum] }}\end{array}$ & $\begin{array}{c}\text { Mean } \pm \text { SD } \\
\text { [minimum, maximum] }\end{array}$ & $\begin{array}{c}\text { Mean } \pm \text { SD } \\
{[\text { minimum, maximum] }}\end{array}$ & $\begin{array}{c}\text { Mean } \pm \text { SD } \\
{[\text { minimum, maximum] }}\end{array}$ & $\begin{array}{c}\text { Mean } \pm \text { SD } \\
\text { [minimum, maximum] }\end{array}$ \\
\hline \multicolumn{6}{|l|}{ Litter characteristics } \\
\hline \multirow[t]{2}{*}{ Total born, $n$} & $15.8 \pm 2.92$ & $18.5 \pm 3.73$ & $15.8 \pm 2.86$ & $17.4 \pm 4.10$ & $18.7 \pm 2.78$ \\
\hline & {$[11,21]$} & {$[11,27]$} & {$[11,22]$} & {$[11,23]$} & {$[14,25]$} \\
\hline \multirow[t]{2}{*}{ Live born, $n$} & $15.1 \pm 3.00$ & $17.3 \pm 3.52$ & $14.9 \pm 2.26$ & $16.9 \pm 3.83$ & $17.3 \pm 2.84$ \\
\hline & {$[10,21]$} & {$[10,26]$} & {$[11,20]$} & {$[10,21]$} & {$[13,24]$} \\
\hline \multirow[t]{2}{*}{ Stillborn, ${ }^{1} n$} & 0.00 & 1.00 & 0.00 & 0.00 & 1.00 \\
\hline & {$[0,5]$} & {$[0,4]$} & {$[0,4]$} & {$[0,2]$} & {$[0,5]$} \\
\hline \multirow{2}{*}{$\begin{array}{l}\text { Litter weight at birth, }{ }^{2} \\
\text { kg }\end{array}$} & $21.8 \pm 3.48$ & $21.0 \pm 4.27$ & $20.6 \pm 2.84$ & $20.6 \pm 4.00$ & $22.5 \pm 3.57$ \\
\hline & {$[12.6,30.5]$} & {$[13.0,31.3]$} & {$[15.1,27.4]$} & {$[13.5,25.7]$} & {$[17.1,27.9]$} \\
\hline \multirow{2}{*}{$\begin{array}{l}\text { Mean litter size in } \\
\text { lactation, } n\end{array}$} & $11.4 \pm 0.93$ & $12.5 \pm 1.33$ & $11.9 \pm 1.27$ & $11.7 \pm 0.81$ & $12.9 \pm 1.49$ \\
\hline & {$[8.77,12.0]$} & {$[8.00,14.0]$} & {$[9.00,14.0]$} & {$[10.0,13.0]$} & {$[8.00,14.0]$} \\
\hline \multicolumn{6}{|l|}{ Farrowing characteristics } \\
\hline \multirow[t]{2}{*}{ Farrowing length, $\mathrm{h}$} & 4.83 & 5.50 & 6.36 & 5.53 & 4.42 \\
\hline & {$[1.92,9.90]$} & {$[1.45,14.8]$} & {$[2.65,11.0]$} & {$[2.37,10.3]$} & {$[2.03,12.5]$} \\
\hline \multirow[t]{2}{*}{ Birth interval, min } & $21.9 \pm 10.6$ & $21.8 \pm 10.6$ & $27.1 \pm 10.2$ & $19.9 \pm 8.70$ & $16.6 \pm 8.97$ \\
\hline & {$[9.3,54]$} & {$[7.9,59]$} & {$[13,57]$} & {$[7.3,29]$} & {$[7.4,42]$} \\
\hline \multirow{2}{*}{$\begin{array}{l}\text { Colostrum availability, } \\
\text { min }\end{array}$} & - & $17.8 \pm 14.9$ & $19.8 \pm 13.6$ & $22.4 \pm 12.7$ & $15.7 \pm 15.2$ \\
\hline & - & {$[2.0,65]$} & {$[3.0,50]$} & {$[5.0,45]$} & {$[5.0,60]$} \\
\hline \multirow[t]{2}{*}{ Colostrum removal, \% } & - & $0.60 \pm 0.05$ & $0.57 \pm 0.07$ & $0.58 \pm 0.09$ & $0.59 \pm 0.07$ \\
\hline & - & {$[0.50,0.68]$} & {$[0.42,0.75]$} & {$[0.43,0.68]$} & {$[0.47,0.71]$} \\
\hline \multicolumn{6}{|l|}{ Colostrum composition } \\
\hline \multirow[t]{2}{*}{ Fat, $\%$} & $5.98 \pm 1.30$ & $5.03 \pm 0.93$ & $5.52 \pm 1.36$ & $4.66 \pm 1.47$ & $5.12 \pm 1.64$ \\
\hline & {$[3.82,9.21]$} & {$[3.58,6.92]$} & {$[2.91,8.15]$} & {$[3.03,7.81]$} & {$[3.04,8.33]$} \\
\hline \multirow[t]{2}{*}{ Protein, \% } & $15.4 \pm 1.75$ & $17.6 \pm 2.15$ & $17.0 \pm 2.48$ & $16.5 \pm 2.36$ & $15.8 \pm 2.26$ \\
\hline & {$[12.4,21.3]$} & {$[14.0,23.1]$} & {$[13.6,21.7]$} & {$[13.9,20.1]$} & {$[12.9,19.2]$} \\
\hline \multirow[t]{2}{*}{ Lactose, $\%$} & $2.99 \pm 0.38$ & $3.49 \pm 0.23$ & $3.16 \pm 0.46$ & $3.40 \pm 0.29$ & $3.72 \pm 0.22$ \\
\hline & {$[1.87,3.57]$} & {$[2.73,3.86]$} & {$[2.04,3.79]$} & {$[2.94,3.66]$} & {$[3.41,4.03]$} \\
\hline \multirow[t]{2}{*}{$\mathrm{DM}, \%$} & $27.2 \pm 2.43$ & $27.2 \pm 2.37$ & $26.8 \pm 3.27$ & $25.9 \pm 2.44$ & $26.0 \pm 3.17$ \\
\hline & {$[22.1,34.1]$} & {$[23.1,34.3]$} & {$[21.8,33.4]$} & {$[22.7,30.1]$} & {$[22.5,32.4]$} \\
\hline \multirow[t]{2}{*}{$\mathrm{GE}, \mathrm{kJ} / 100 \mathrm{~g}$} & $649 \pm 70.4$ & $671 \pm 63.7$ & $670 \pm 94.6$ & $628 \pm 68.6$ & $636 \pm 93.4$ \\
\hline & {$[513,823]$} & {$[573,860]$} & {$[515,870]$} & {$[539,728]$} & {$[521,837]$} \\
\hline \multicolumn{6}{|l|}{ Milk composition ${ }^{3}$} \\
\hline \multirow[t]{2}{*}{ Fat, \% } & $7.09 \pm 1.22$ & $8.50 \pm 1.41$ & - & $7.30 \pm 1.60$ & $8.26 \pm 1.19$ \\
\hline & {$[4.38,10.0]$} & {$[5.70,17.4]$} & - & {$[5.36,14.0]$} & {$[5.39,15.1]$} \\
\hline \multirow[t]{2}{*}{ Protein, \% } & $4.67 \pm 0.33$ & $5.00 \pm 0.45$ & - & $5.10 \pm 0.45$ & $4.77 \pm 0.35$ \\
\hline & {$[3.99,5.56]$} & {$[3.97,7.54]$} & - & {$[4.02,6.76]$} & {$[3.69,6.04]$} \\
\hline \multirow[t]{2}{*}{ Lactose, \% } & $5.84 \pm 0.33$ & $4.99 \pm 0.21$ & - & $5.11 \pm 0.16$ & $5.03 \pm 0.20$ \\
\hline & {$[3.21,6.49]$} & {$[4.44,5.66]$} & - & {$[4.66,5.52]$} & {$[4.36,5.53]$} \\
\hline \multirow[t]{2}{*}{$\mathrm{DM}, \%$} & $18.8 \pm 1.24$ & $19.4 \pm 1.47$ & - & $18.1 \pm 1.80$ & $19.0 \pm 1.13$ \\
\hline & {$[15.5,21.9]$} & {$[16.8,29.3]$} & - & {$[15.5,25.7]$} & {$[16.1,25.7]$} \\
\hline \multirow[t]{2}{*}{$\mathrm{GE}, \mathrm{kJ} / 100 \mathrm{~g}$} & $483 \pm 47.8$ & $532 \pm 58.0$ & - & $489 \pm 68.8$ & $518 \pm 44.3$ \\
\hline & {$[372,603]$} & {$[424,928]$} & - & {$[392,780]$} & {$[401,791]$} \\
\hline
\end{tabular}

${ }^{1}$ The number of stillborn piglets and the length of farrowing were skewed; therefore, the median is given instead of the mean and the SD.

${ }^{2}$ Only live-born piglets included.

${ }^{3}$ Traits were measured weekly but here data represents mean for $4 \mathrm{wk}$ of lactation.

\section{RESULTS}

\section{Sow and Litter}

Sow parity ranked from first to fifth parity with $82 \%$ of the sows being of second parity. Sows weighed
$265 \pm 27.7 \mathrm{~kg}$ before farrowing and had $19.5 \pm 5.9$ $\mathrm{mm}$ of back fat. The ADFI a week before lactation was $2.7 \pm 0.38 \mathrm{~kg}$ feed/sow with the mean daily ME intake ranging from 24 to $44 \mathrm{MJ} /$ day. During the whole lactation period, ADFI intake was $6.42 \pm 0.72 \mathrm{~kg}$ feed/ sow with mean daily protein and fat intake ranging 
Table 4. Pearson correlation coefficients between all dependent variables ${ }^{1}$ describing sow productivity

\begin{tabular}{lcccccc}
\hline \hline Item & Onset of lactation & Transition MY & MY1 & MY2 & MY3 & MY4 \\
\hline CY & 0.02 & $0.31^{*}$ & $0.22^{*}$ & $0.24^{* *}$ & 0.11 & 0.15 \\
Onset of lactation & & $0.37^{*}$ & $-0.27^{*}$ & $-0.29^{*}$ & -0.21 & $-0.30^{*}$ \\
Transition MY & & & 0.18 & 0.20 & $0.28^{\dagger}$ & 0.15 \\
MY1 & & & $0.88^{* * *}$ & $0.66^{* * *}$ & $0.53^{* * *}$ \\
MY2 & & & & $0.74^{* * *}$ & $0.59^{* * *}$ \\
MY3 & & & & & $0.84^{* * *}$ \\
\hline
\end{tabular}

${ }^{1} \mathrm{CY}=$ colostrum yield. Onset of lactation is the time for abruptly increased milk secretion. Transition milk yield (MY) is the MY 48 to $60 \mathrm{~h}$ postpartum. MY1, MY2, MY3, and MY4 = mean MY in wk 1,2,3, and 4, respectively.

$\dagger P \leq 0.10 ; * P \leq 0.05 ; * * P \leq 0.01 ; * * * P \leq 0.001$.

from 425 to $1,662 \mathrm{~g} / \mathrm{d}$ and from 144 to $856 \mathrm{~g} / \mathrm{d}$, respectively (Table 2). The mean gestation length was 116 $\pm 1.6 \mathrm{~d}$ and the median of farrowing length was $5.1 \mathrm{~h}$, with the shortest and longest farrowing being 1.5 and $14.8 \mathrm{~h}$, respectively (Table 3 ). The mean birth interval of piglets for individual sows varied from 7 to 53 $\mathrm{min}$. In relation to colostrum availability, it took from 2 to $60 \mathrm{~min}$ to hand milk the $50 \mathrm{~mL}$ colostrum sample, whereas the median was $14 \mathrm{~min}$. The mean number of live-born piglets was $16.0 \pm 3.2$ piglets/litter and ranged from 10 to 26 piglets/litter, and the number of stillborn piglets per litter varied from 0 to 5 piglets with a median of 1 piglet. Of the live-born piglets, $4.5 \%$ died within the colostrum period (i.e., until 24 $\mathrm{h}$ after parturition started). The mean litter weight of live-born piglets at birth was $21.3 \pm 3.6 \mathrm{~kg}$ and varied between 12.6 and $31.3 \mathrm{~kg}$ (Table 3 ).

\section{Sow Productivity}

The CY ranked from a minimum of $2.8 \mathrm{~kg} / \mathrm{d}$ to a maximum of $8.5 \mathrm{~kg} / \mathrm{d}$ and the mean CY was $6.0 \pm$ $1.1 \mathrm{~kg} / \mathrm{d}$. Onset of lactation began earliest at $22.5 \mathrm{~h}$ and no later than $39.4 \mathrm{~h}$ after parturition started with the mean being $30.9 \pm 3.7 \mathrm{~h}$ postpartum. The lowest and highest value observed for transition MY was 3.5 and $11.9 \mathrm{~kg} / \mathrm{d}$, respectively, and the mean transition MY was $6.8 \pm 2.0$ $\mathrm{kg} / \mathrm{d}$. The MY peaked in the third week of lactation and the estimated mean values of weekly MY in the $4 \mathrm{wk}$ of lactation were $8.4 \pm 0.8,11.9 \pm 1.7,13.1 \pm 2.0$, and $12.9 \pm 2.2 \mathrm{~kg} / \mathrm{d}$, respectively. The Pearson correlation analysis between the dependent variables showed that the CY was positively correlated with the transition MY and MY in wk 1 and 2 of lactation $(P<0.05$; Table 4$)$. Time for onset of lactation was positively correlated with transition MY but negatively correlated with MY in wk 1 , 2 , and 4 of lactation $(P<0.05$; Table 4$)$. In addition, the mean weekly MY during lactation were strongly positively correlated with each other $(P<0.001$; Table 4$)$.

\section{Correlations between Dependent and Independent Variables}

Colostrum Yield. The Pearson correlation analysis showed CY to be positively correlated with ADFI from $\mathrm{d}-7$ to $-3, \mathrm{BW}_{\text {sow }}$ on $\mathrm{d}-8, \mathrm{BW}_{\text {sow }}$ on $\mathrm{d} 3$, the number of total born and live-born piglets, litter weight at birth, litter size $24 \mathrm{~h}$ postpartum, and the concentration of lactose in colostrum. But CY was negatively correlated with the loss of back fat from a week before parturition until weaning (Table 5).

Onset of Lactation and Transition Milk Yield. Onset of lactation was not influenced by any of the independent variables included in this study. Transition MY was positively correlated with $\mathrm{BW}_{\text {sow }}$ on $\mathrm{d}-8$, the number of total born and live-born piglets, the litter weight at birth, and the litter size $24 \mathrm{~h}$ postpartum. But transition MY was negatively correlated with the $\mathrm{ADFI}$ and mean daily ME intake in the last $2 \mathrm{~d}$ prepartum (Table 5).

Milk Yield during Lactation. The mean weekly MY in the $4 \mathrm{wk}$ of lactation were all positively correlated with the mean litter size (Table 6). In addition, MY1 was positively correlated with $\mathrm{BW}_{\text {sow }}$ on $\mathrm{d} 3$ and gestation length but negatively correlated with ADFI; mean daily intake of protein, fat, Lys, Thr, and Val in wk 1; and the loss of back fat during lactation. The MY2 was additionally positively correlated with back fat thickness prepartum and concentrations of fat and GE in milk during wk 2 ; however, it was negatively correlated with the mean daily intake of protein, fat, Lys, Thr, and Val in wk 2; the loss of back fat and loss of $\mathrm{BW}_{\text {sow }}$ during lactation; and the protein and lactose concentration in milk during wk 2 of lactation. Furthermore, the MY3 was positively correlated with ADFI in wk 3 and negatively correlated with the loss of $\mathrm{BW}_{\text {sow }}$ during lactation and the milk protein concentration in wk 3 of lactation. The MY4 was also positively correlated with ADFI in wk 4 and the gestation length and negatively correlated with the milk protein concentration in wk 4 of lactation (Table 6). 
Table 5. Pearson coefficient of correlations between colostrum yield (CY), onset of lactation, and transition milk yield (MY) and the independent variables describing sow nutrition, litter characteristics, farrowing characteristics, and composition of colostrum

\begin{tabular}{|c|c|c|c|c|c|c|c|c|c|}
\hline \multirow[b]{2}{*}{ Item } & \multicolumn{3}{|c|}{$\mathrm{CY}, \mathrm{kg} / \mathrm{d}$} & \multicolumn{3}{|c|}{ Onset of lactation, $\mathrm{h}$} & \multicolumn{3}{|c|}{ Transition MY, kg/d } \\
\hline & $r$ & $P$-value & $n$ & $r$ & $P$-value & $n$ & $r$ & $P$-value & $n$ \\
\hline \multicolumn{10}{|l|}{ Sow nutrition } \\
\hline ADFI (d -7 to -3 ), kg feed/d & 0.24 & $*$ & 97 & 0.01 & $\mathrm{NS}^{1}$ & 34 & 0.28 & $\dagger$ & 43 \\
\hline ADFI (d -2 to 0$), \mathrm{kg}$ feed/d & 0.19 & $\dagger$ & 97 & -0.04 & NS & 34 & -0.37 & $*$ & 43 \\
\hline Daily ME intake (d -7 to -3$), M J / d$ & 0.17 & $\dagger$ & 97 & 0.06 & NS & 34 & 0.22 & NS & 43 \\
\hline Daily $M E$ intake (d -2 to 0$), M J / d$ & 0.17 & $\dagger$ & 97 & -0.01 & NS & 34 & -0.40 & $* *$ & 43 \\
\hline $\mathrm{BW}_{\text {sow }}{ }^{2} \mathrm{~d}-8, \mathrm{~kg}$ & 0.48 & $* * *$ & 96 & 0.13 & NS & 34 & 0.34 & $*$ & 43 \\
\hline $\mathrm{BW}_{\text {sow }} \mathrm{d} 3, \mathrm{~kg}$ & 0.32 & $*$ & 51 & 0.17 & NS & 33 & 0.21 & NS & 43 \\
\hline Loss of $\mathrm{BW}_{\text {sow }} \mathrm{d}-8$ to $3, \mathrm{~kg}$ & -0.13 & NS & 49 & 0.16 & NS & 33 & -0.28 & $\dagger$ & 42 \\
\hline Back fat $\mathrm{d}-8, \mathrm{~mm}$ & 0.19 & $*$ & 118 & 0.14 & NS & 54 & 0.01 & NS & 43 \\
\hline Loss of back fat d -8 to $28, \mathrm{~mm}$ & -0.26 & $*$ & 91 & 0.15 & NS & 32 & -0.09 & NS & 43 \\
\hline \multicolumn{10}{|l|}{ Litter characteristics } \\
\hline Total born, $\mathrm{n}$ & 0.36 & $* * *$ & 119 & 0.08 & NS & 54 & 0.30 & $*$ & 43 \\
\hline Live born, $\mathrm{n}$ & 0.43 & $* * *$ & 119 & 0.06 & NS & 54 & 0.35 & $*$ & 43 \\
\hline Odds stillborn, $\%$ & -0.14 & NS & 119 & 0.10 & NS & 54 & -0.11 & NS & 43 \\
\hline Litter weight at birth, $\mathrm{kg}$ & 0.61 & $* * *$ & 119 & 0.19 & NS & 54 & 0.43 & $* *$ & 43 \\
\hline Litter size 24 h, n & 0.52 & $* * *$ & 119 & 0.13 & NS & 54 & 0.40 & $* *$ & 43 \\
\hline \multicolumn{10}{|l|}{ Farrowing characteristics } \\
\hline Gestation length, $\mathrm{d}$ & 0.13 & NS & 118 & 0.18 & NS & 54 & -0.08 & NS & 43 \\
\hline Farrowing length, $\mathrm{h}$ & 0.03 & NS & 119 & 0.13 & NS & 54 & 0.29 & $\dagger$ & 43 \\
\hline Mean birth interval, min & -0.16 & $\dagger$ & 117 & 0.02 & NS & 53 & 0.19 & NS & 43 \\
\hline Colostrum availability, $\min$ & -0.15 & NS & 70 & 0.17 & NS & 52 & -0.02 & NS & 43 \\
\hline Colostrum removal, \% & 0.20 & $\dagger$ & 73 & -0.03 & NS & 54 & 0.09 & NS & 43 \\
\hline \multicolumn{10}{|l|}{ Colostrum composition } \\
\hline Fat, $\%$ & -0.12 & NS & 113 & - & - & - & - & - & - \\
\hline Protein, \% & 0.02 & NS & 113 & - & - & - & - & - & - \\
\hline Lactose, \% & 0.28 & $* *$ & 113 & - & - & - & - & - & - \\
\hline $\mathrm{DM}, \%$ & -0.10 & NS & 113 & - & - & - & - & - & - \\
\hline $\mathrm{GE}, \mathrm{kJ} / 100 \mathrm{~g}$ & -0.04 & NS & 113 & - & - & - & - & - & - \\
\hline
\end{tabular}

\section{Regression Analysis}

The results of the multivariate regression analysis are shown in Table 7. The results indicated that $58 \%$ of the variation within $\mathrm{CY}$ was explained by the litter weight of live-born piglets at birth, which contributed with a positive regression coefficient of 0.20 . None of the other independent variables were statistically related with $\mathrm{CY}$ when the litter weight at birth was included, but it should be noted that strong positive correlations $(P<0.001)$ were found between litter weight at birth and the number of live-born piglets $(r=0.64)$ and between litter weight at birth and number of total born piglets $(r=0.56)$.

Onset of lactation was not significantly influenced by any of the chosen independent variables. However, onset of lactation tended to happen earlier $(P=0.06)$ in litters that received cross-fostered piglets for litter equalization $(29.1 \pm 1.1 \mathrm{~h})$ compared with litters that did not receive cross-fostered piglets $(31.5 \pm 0.7 \mathrm{~h})$. Colostrum

yield, transition MY, and weekly MY were not affected by cross-fostering ( $P>0.10$; data not shown). In relation to transition MY, then, the daily intake of ME in the last $2 \mathrm{~d}$ before parturition and the litter size 24 h postpartum explained $33 \%$ of the variability within transition MY. The daily intake of ME contributed with a negative regression coefficient of -0.30 and the litter size with a positive regression coefficient of 0.27 .

All the regression models related to the weekly MY included litter size and milk protein concentration in the current weeks. The regression coefficients for litter sizes were positive whereas the regression coefficients for the milk protein concentrations were negative for all lactation weeks. The regression model for MY1 indicated that litter size, milk protein concentration, and $\mathrm{BW}_{\text {sow }}$ at d 3 explained $96 \%$ of the variability within MY1. The $\mathrm{BW}_{\text {sow }}$ at $\mathrm{d} 3$ had a positive regression coefficient. With regards to the regression models for MY2, MY3, and 
Table 6. Pearson coefficient of correlations between milk yield in wk 1 through 4 (MY1, MY2, MY3, and MY4) and independent variables describing sow nutrition, litter characteristics, farrowing characteristics, and milk composition

\begin{tabular}{|c|c|c|c|c|c|c|c|c|c|}
\hline \multirow[b]{2}{*}{ Item } & \multirow[b]{2}{*}{$n$} & \multicolumn{2}{|c|}{$\mathrm{MY} 1, \mathrm{~kg} / \mathrm{d}$} & \multicolumn{2}{|c|}{$\mathrm{MY} 2, \mathrm{~kg} / \mathrm{d}$} & \multicolumn{2}{|c|}{$\mathrm{MY} 3, \mathrm{~kg} / \mathrm{d}$} & \multicolumn{2}{|c|}{$\mathrm{MY} 4, \mathrm{~kg} / \mathrm{d}$} \\
\hline & & $r$ & $P$-value & $r$ & $P$-value & $r$ & $P$-value & $R$ & $P$-value \\
\hline \multicolumn{10}{|l|}{ Sow nutrition } \\
\hline $\mathrm{ADFI},{ }^{1} \mathrm{~kg}$ & 90 & -0.34 & $* * *$ & 0.12 & $\mathrm{NS}^{2}$ & 0.29 & $* *$ & 0.31 & $* *$ \\
\hline Mean daily protein intake, ${ }^{1} \mathrm{~g}$ & 90 & -0.55 & $* * *$ & -0.35 & $* * *$ & 0.05 & NS & 0.12 & NS \\
\hline Mean daily fat intake, ${ }^{1} \mathrm{~g}$ & 90 & -0.46 & $* * *$ & -0.37 & $* * *$ & -0.07 & NS & 0.01 & NS \\
\hline Mean daily Lys intake, ${ }^{1} \mathrm{~g}$ & 87 & -0.52 & $* * *$ & -0.35 & $* * *$ & 0.06 & NS & 0.12 & NS \\
\hline Mean daily Thr intake, ${ }^{1} \mathrm{~g}$ & 87 & -0.59 & $* * *$ & -0.45 & $* * *$ & -0.02 & NS & 0.05 & NS \\
\hline Mean daily Val intake, ${ }^{1} \mathrm{~g}$ & 87 & -0.61 & $* * *$ & -0.47 & $* * *$ & -0.07 & NS & 0.01 & NS \\
\hline $\mathrm{BW}_{\text {sow }}{ }^{3} \mathrm{~d} 3, \mathrm{~kg}$ & 49 & 0.28 & $*$ & 0.25 & $\dagger$ & 0.00 & NS & 0.05 & NS \\
\hline $\mathrm{BW}_{\text {sow }} \mathrm{d} 28, \mathrm{~kg}$ & 90 & - & - & - & - & - & - & 0.07 & NS \\
\hline Loss of BW ${ }_{\text {sow }}$ d 3 to $28, \mathrm{~kg}$ & 47 & -0.20 & NS & -0.32 & $*$ & -0.38 & $* *$ & -0.20 & $\dagger$ \\
\hline Back fat $\mathrm{d}-8, \mathrm{~mm}$ & 106 & 0.01 & NS & 0.05 & NS & 0.09 & NS & 0.02 & NS \\
\hline Back fat d $28, \mathrm{~mm}$ & 90 & - & - & - & - & - & - & -0.15 & NS \\
\hline Loss of back fat $\mathrm{d}-8$ to $28, \mathrm{~mm}$ & 89 & -0.14 & NS & -0.28 & $* *$ & -0.08 & NS & -0.12 & NS \\
\hline \multicolumn{10}{|l|}{ Litter characteristics } \\
\hline Live born, $n$ & 107 & 0.08 & NS & 0.11 & NS & 0.04 & NS & 0.06 & NS \\
\hline Odds stillborn, \% & 106 & 0.08 & NS & 0.11 & NS & 0.04 & NS & 0.08 & NS \\
\hline Mean litter size, ${ }^{1} n$ & 107 & 0.96 & $* * *$ & 0.88 & $* * *$ & 0.73 & $* * *$ & 0.60 & $* * *$ \\
\hline \multicolumn{10}{|l|}{ Farrowing characteristics } \\
\hline Gestation length, $d$ & 106 & 0.25 & $* *$ & 0.14 & NS & 0.13 & NS & 0.19 & $*$ \\
\hline Farrowing length, $h$ & 105 & 0.06 & NS & -0.04 & NS & -0.03 & NS & -0.06 & NS \\
\hline Mean birth interval, $\min$ & 105 & -0.01 & NS & -0.12 & NS & -0.09 & NS & -0.11 & NS \\
\hline Colostrum availability, $\min$ & 60 & -0.07 & NS & -0.17 & NS & -0.09 & NS & -0.10 & NS \\
\hline Colostrum removal, $\%$ & 62 & 0.04 & NS & 0.11 & NS & 0.19 & NS & 0.12 & NS \\
\hline \multicolumn{10}{|l|}{ Milk composition $^{1}$} \\
\hline Fat, $\%$ & 86 & 0.08 & NS & 0.40 & $* * *$ & 0.00 & NS & -0.11 & NS \\
\hline Protein, $\%$ & 86 & -0.20 & NS & -0.42 & $* * *$ & -0.27 & $* *$ & -0.32 & $* *$ \\
\hline Lactose, $\%$ & 86 & 0.00 & NS & -0.59 & $* * *$ & -0.11 & NS & 0.02 & NS \\
\hline $\mathrm{DM}, \%$ & 86 & 0.01 & NS & 0.06 & NS & -0.12 & NS & -0.21 & $\dagger$ \\
\hline $\mathrm{GE}, \mathrm{kJ} / 100 \mathrm{~g}$ & 86 & 0.01 & NS & 0.26 & $*$ & -0.06 & NS & -0.17 & NS \\
\hline
\end{tabular}

MY4, then, litter size and the milk protein concentration explained 88,69 , and $54 \%$ of the variability, respectively.

\section{DISCUSSION}

A high CY was found to positively relate with the transition MY and MY in the first 2 wk of lactation. This indicates that maximizing the $\mathrm{CY}$ can both increase piglet survival (Quesnel et al., 2013) and enhance piglet growth. Besides, late onset of lactation was beneficial for the transition MY but negative for the mean MY during lactation. Hence, the time for onset of lactation seemed to affect the shape of the lactation curve and could be a potential key to enhance milking ability of sows, even though none of the observed traits except litter equilization in the present study were able to explain the individual differences in time for onset of lactation. In addition to insights into when onset of lactation oc- curs, it will be important also to gain greater insights into what regulates the onset of lactation. Moreover, as expected, the mean weekly MY during lactation were strongly positively correlated between lactation weeks, which also clearly was shown by Hansen et al. (2012a).

\section{Colostrum Yield}

The present study revealed that litter weight (and litter size) at birth was positively associated with sow CY. It is well known that litter size influences MY of sows (King, 2000; Nielsen et al., 2001), but to our knowledge, this study is the first to report a positive correlation between litter weight (or litter size) and the CY. Previous studies did not document any relations between $\mathrm{CY}$ and litter size (Le Dividich et al., 2005; Devillers et al., 2007; Foisnet et al., 2010; Quesnel et al., 2012; Decaluwé et al., 2012); however, the use of different prediction mod- 
Table 7. Regression models determined through stepwise regression with a backward elimination approach for colostrum yield (CY), transition milk yield (MY), and the mean MY in wk 1, 2, 3, and 4 (MY1, MY2, MY3, and MY4)

\begin{tabular}{|c|c|}
\hline Regression model $^{1}$ & $R^{2}$ \\
\hline $\mathrm{CY}(\mathrm{kg} / \mathrm{d})=1.10+0.20 \times$ total litter weight at birth $(\mathrm{kg})$ & 0.58 \\
\hline Transition MY $(\mathrm{kg} / \mathrm{d})=12.2-0.30 \times \mathrm{ME}_{\mathrm{d}-2 \text { to } 0}(\mathrm{MJ} / \mathrm{d})+0.27 \times$ litter size $24 \mathrm{~h}$ after parturition & 0.33 \\
\hline Onset of lactation ${ }^{2}(h)=31.5-2.4 \times I$ & 0.20 \\
\hline MY1 $(\mathrm{kg} / \mathrm{d})=0.54+0.66 \times$ litter size $_{\mathrm{wk} 1}-0.17 \times$ milk protein $_{\mathrm{wk} 1}(\mathrm{~g} / 100 \mathrm{~g})+0.0020 \times \mathrm{BW}_{\mathrm{d} 3}(\mathrm{~kg})$ & 0.96 \\
\hline MY2 $(\mathrm{kg} / \mathrm{d})=4.55+1.01 \times$ litter size $_{\mathrm{wk} 2}-1.00 \times$ milk protein $_{\mathrm{wk} 2}(\mathrm{~g} / 100 \mathrm{~g})$ & 0.88 \\
\hline MY3 $(\mathrm{kg} / \mathrm{d})=5.96+1.14 \times$ litter size $_{\mathrm{wk} 3}-1.32 \times$ milk protein $_{\mathrm{wk} 3}(\mathrm{~g} / 100 \mathrm{~g})$ & 0.69 \\
\hline MY4 $(\mathrm{kg} / \mathrm{d})=9.10+0.95 \times$ litter size $_{\mathrm{wk} 4}-1.57 \times$ milk protein $_{\mathrm{wk} 4}(\mathrm{~g} / 100 \mathrm{~g})$ & 0.54 \\
\hline
\end{tabular}

${ }^{1}$ The fixed effects of experiment and treatment within experiment were included in all multivariate regression models.

${ }^{2} I$ is an indicator function representing litters that $\operatorname{did} \operatorname{not}(I=0)$ or $\operatorname{did}(I=1)$ receive piglets for litter equalization.

els to quantify colostrum intake of the piglets might explain this discrepancy. Theil et al. (2014a) reported that the model used by Devillers et al. (2007), Foisnet et al. (2010), Quesnel (2011), and Decaluwé et al. (2013) underestimated colostrum intake of the piglets by $30 \%$ compared with the model used to derive colostrum intake in the present paper. Furthermore, a higher number of observations used in this study might be a decisive factor. It may be speculated that the positive relation between litter weight or litter size and CY is an effect of a higher number of glands stimulated in larger litters as previously reported for MY (Auldist et al., 1998; King, 2000; Hurley, 2001). Currently, it is unknown when colostrum is actually produced (Theil, 2015). Depending on whether colostrum is mainly produced before or after onset of parturition, the effect of litter size might also be related with hormones involved in both fetal development and lactogenesis in the last part of gestation or related with more efficient colostrum removal or both.

\section{Onset of Lactation and Transition Milk Yield}

A relatively high variation among individuals was observed for onset of lactation, which formed the basis for expecting relations with some of the studied independent variables. However, no relations were detected between onset of lactation and the independent variables, which could be due to a lack of precision when using the broken line method. Nevertheless, onset of lactation seemed to affect shape of the lactation curve. In addition, time of onset of lactation may be related to consequences of litter equalization, which is known to induce stress. Indeed, litters with fewer live-born piglets than functional mammary glands received cross-fostered piglets around the time of the onset of lactation, whereas litters with numerous piglets did not receive crossfostered piglets. However, onset of lactation tended to occur earlier for sows that had received cross-fostered piglets, indicating that potential stress imposed by crossfostering did not delay onset of lactation. Moreover, it could be speculated that a faster onset of lactation in cross-fostered litters could be due to more intense suckling stimuli from more vigorous piglets.

Transition MY was positively influenced by the litter size $24 \mathrm{~h}$ after parturition and negatively influenced by the mean daily intake of ME just before parturition. The positive influence of litter size is likely related with the number of milk-producing glands and more efficient stimulation of milk synthesis in large litters (Auldist et al., 1998). The fact that the litter size $24 \mathrm{~h}$ after parturition instead of the number of liveborn piglets was included in the regression model was probably related to the fact that $4.5 \%$ of the newborn piglets died during the colostrum period. According to the multivariate model describing transition MY, a high energy intake in the last $2 \mathrm{~d}$ prepartum was found to inhibit the transition MY. A similar effect has been indicated on MY in the first week of lactation where increased feed intake in late gestation reduced the MY in early lactation (Danielsen, 2003; Laws et al., 2009). The mechanisms behind this observation have not been fully elucidated but a high energy intake in late gestation might increase the risk of developing metritis, mastitis, or agalactia (Danielsen, 2003) or it may suppress the feed intake in early lactation (Weldon et al., 1994; Revell et al., 1998; Prunier et al., 2001). Furthermore, it has been suggested that a high energy intake in late gestation negatively affects mammogenesis (Farmer et al., 2004).

\section{Milk Yield in Established Lactation}

In the current study, the mean litter size positively influenced MY in all $4 \mathrm{wk}$ of lactation. These results complied with the positive linear relationship between litter size and MY previously described in the literature (Auldist et al., 1998; King, 2000; Nielsen et al., 2002). Auldist et al. (1998) explained the increased MY as an effect of a higher number of functional teats due to the increased litter size. In this study, litter equalization differed between the included experiments but the size of the equalized litter did not exceed the number 
of mammary glands, and as a corollary, the higher MY was likely explained by a higher number of milk-producing glands. Besides, an increased demand for milk from larger litters has been reported to improve mammary development (Auldist et al., 1995).

The concentration of protein in mature milk has previously been considered being rather constant, irrespective of the piglet weight gain or sow MY (King and Dunkin, 1986b; Klobasa et al., 1987; Theil et al., 2012). Remarkably, in the current study, the milk protein concentration was included in all the regression models for MY with negative regression coefficients, meaning that a low milk protein concentration was associated with a high MY. In line with that finding, Garst et al. (1999) investigated the effect of machine milking sows and found that the milk protein concentration decreased linearly with increasing MY. Furthermore, Auldist et al. (1998) documented that the milk protein concentration quadratically decreased with increasing litter size in late lactation (litter size being positively related with MY). An inverse relationship between MY and milk protein concentration has also been reported for dairy cows either as a consequence of declining MY and increasing milk protein concentration after peak lactation or as a consequence of improved individual MY using dietary fat, which depresses milk protein concentration (Hullar and Brand, 1993). The inverse relationship for both cows and sows may be due to a dilution of secreted milk protein due to increased milk production without a concomitant increase in synthesis of milk solids. Alternatively, the inverse relationship in the present study could suggest that the hyperprolific sows were not adequately supplied with dietary nutrients (protein, essential AA, and/or energy) and that mobilization of AA from muscles could be a limiting factor for their milk protein synthesis. In line with that, Jones and Stahly (1999) demonstrated that sows feed a low-protein diet ( $0.34 \%$ Lys) had a lower milk protein concentration throughout lactation compared with sows feed a high-protein diet (1.2\% Lys). Similarly, positive relations between dietary protein intake and the protein concentration in milk have been reported by King and Dunkin (1986b), King et al. (1993), Kusina et al. (1999), and Guan et al. (2004). In contrast, changing the dietary energy density will more likely affect only the MY rather than the milk protein concentration (Noblet et al., 1998; Beyer et al., 2007). Therefore, is seems likely that the productivity of the highly prolific sows in the present study was limited by the dietary supplies of protein and/or essential AA, even though sows in the 5 experiments were fed according to current Danish recommendations. In support of that theory, the mean concentration of protein $(4.88 \mathrm{~g} / 100 \mathrm{~g}$ milk) in this study was substantially lower than reported in other studies
(Schoenherr et al., 1989; Csapo et al., 1996; Garst et al., 1999; Theil et al., 2012; Hansen et al., 2012b). Most likely this is due to a higher demand for protein and essential AA in modern high-yielding sows. Indeed, sows were fed approximately $6 \mathrm{~g}$ of digestible Lys $/ \mathrm{kg}$ of feed corresponding to a mean daily intake of 50 to $55 \mathrm{~g} / \mathrm{d}$ at peak lactation (data not shown). However, sows that produce $13 \mathrm{~kg} / \mathrm{d}$ of milk at peak lactation secrete $54 \mathrm{~g}$ of Lys (4.12 g/kg of milk; Wu and Knabe, 1994), and consequently, sows that produced better that average were clearly undersupplied with dietary Lys. Although most of the dietary Lys is actually used for milk production, Lys is also required for metabolic purposes other than milk (Theil, 2015).

The $\mathrm{BW}_{\text {sow }}$ at $\mathrm{d} 3$ in the current study had a positive influence on MY in wk 1. This could indicate that the amount of body reserves available for mobilization, including adipose and muscle tissue, influenced the MY in the first week of lactation. Body reserves acts as a buffer of nutrients when the intake of dietary energy and nutrients are insufficient compared with the requirements of the sow, particularly in early lactation (King and Dunkin, 1986a; Noblet et al., 1998; Theil et al., 2012). Parity is confounded with the sow BW, and sow parity has previously been shown to influence MY, primarily because the yield is lower for gilts than for older sows (parity $\geq 2$; Beyer et al., 2007). However, the present study did not reveal effects of parity on yield of colostrum or milk, probably because second-parity sows were greatly overrepresented in the present study.

The explained variation of the regression models for MY declined as lactation progressed, which indicated that parameters not included in this study got more important in late lactation. Furthermore, the SD of calculated MY increased as lactation progressed, which suggests that lactation persistency could be an important factor for sow productivity, even though the lactation period is rather short in sows. Alternatively, the lack of explained variation in later lactation may simply be due the sows' inability to produce enough milk for suckling piglets to reach their genetic growth potential. In line with that, studies using artificially reared piglets or piglets raised by transgenic sows have shown that piglets allowed to consume more milk than usually provided by lactating sows begin to greatly outgrow their sow-reared contemporaries at approximately 8 to $10 \mathrm{~d}$ of age (Boyd et al., 1995; Wheeler et al., 2001).

In conclusion, sow productivity in the colostrum period and at onset of lactation positively affected the MY during lactation. Through the correlation analysis it was suggested that onset of lactation might influence the shape of the lactation curve and that early onset of lactation could be beneficial for the MY during lacta- 
tion. Litter size turned out to be a determining factor for sow productivity in the colostrum period, at onset of lactation, and throughout lactation. Consequently, litter size should always be considered when feeding lactating sows. Furthermore, the present study suggested that modern highly prolific sows could be undersupplied with dietary protein or essential AA and that the synthesis of milk protein in turn may be compromised. Special attention should, therefore, be given to the impact of litter size on MY, because the MY greatly affects the daily requirements for protein and $\mathrm{AA}$. Additionally, it might be rewarding to increase focus on the sow productivity in the colostrum period and at onset of lactation due to its positive influence on MY throughout lactation.

\section{LITERATURE CITED}

Auldist, D., D. Carlson, L. Morrish, C. Wakeford, and R. King. 1995. Effect of increased suckling frequency on mammary development and milk yield of sows. In: D. P. Hennessy and P. D. Cranwell, editors, Manipulating pig production V. Australasian Pig Science Association, Werribee, Victoria, Australia. p. 137 (Abstr.)

Auldist, D., L. Morrish, P. Eason, and R. King. 1998. The influence of litter size on milk production of sows. Anim. Sci. 67:333-338. doi:10.1017/S1357729800010109.

Beyer, M., W. Jentsch, S. Kuhla, H. Wittenburg, F. Kreienbring, H. Scholze, P. E. Rudolph, and C. C. Metges. 2007. Effects of dietary energy intake during gestation and lactation on milk yield and composition of first, second and fourth parity sows. Arch. Anim. Nutr. 61:452-468. doi:10.1080/17450390701563433.

Boyd, R. D., R. S. Kensinger, R. J. Harrell, and D. E. Bauman. 1995. Nutrient uptake and endocrine regulation of milk synthesis by mammary tissue of lactating sows. J. Anim. Sci. 73(Suppl. 2):36-56.

Chwalibog, A. 2006. Næringsværdi og næringsbehov. (Nutritional values and requirements.) (In Danish.) 7th ed. Sam" fundslitteratur, KVL-bogladen, Copenhagen, Denmark.

Csapo, J., T. Martin, Z. Csapo-Kiss, and Z. Hazas. 1996. Protein, fats, vitamin and mineral concentrations in porcine colostrum and milk from parturition to 60 days. Int. Dairy J. 6:881-902. doi:10.1016/0958-6946(95)00072-0.

Danielsen, V. 2003. Fodringsstrategier for diegivende søer. (Feeding strategies for lactating sows.) (In Danish.) Grøn Viden - Husdyrbrug 33:1-8.

Decaluwé, R., G. Janssens, I. Declerck, A. de Kruif, and D. Maes. 2012. Induction of parturition in the sow. Vlaams Diergeneeskd. Tijdschr. 81:158-165.

Decaluwé, R., D. Maes, I. Declerck, A. Cools, B. Wuyts, S. De Smet, and G. P. Janssens. 2013. Changes in back fat thickness during late gestation predict colostrum yield in sows. Animal 7:1999-2007. doi:10.1017/S1751731113001791.

Devillers, N., C. Farmer, J. Le Dividich, and A. Prunier. 2007. Variability of colostrum yield and colostrum intake in pigs. Animal 1:1033-1041. doi:10.1017/S175173110700016X.

Farmer, C., D. Petitclerc, M. T. Sorensen, M. Vignola, and J. Y. Dourmad. 2004. Impacts of dietary protein level and feed restriction during prepuberty on mammogenesis in gilts. J. Anim. Sci. 82:2343-2351.

Farmer, C., and H. Quesnel. 2009. Nutritional, hormonal, and environmental effects on colostrum in sows. J. Anim. Sci. 87:56-64. doi:10.2527/jas.2008-1203.
Flummer, C., H. Lyby, K. S. Storli, V. Bjerre-Harpøth, B. M. Nielsen, M. Krämer, B. A. Røjen, N. B. Kristensen, and P. K. Theil. 2012. Effects of $\beta$-hydroxy $\beta$-methyl butyrate supplementation to sows in late gestation on absorption and hepatic metabolism of glucose and amino acids during transition. J. Anim. Sci. 90(Suppl. 4):146-148. doi:10.2527/jas.53831.

Foisnet, A., C. Farmer, C. David, and H. Quesnel. 2010. Relationships between colostrum production by primiparous sows and sow physiology around parturition. J. Anim. Sci. 88:1672-1683. doi:10.2527/jas.2009-2562.

Garst, A., S. Ball, B. Williams, C. Wood, J. Knight, H. Moll, C. H. Aardema, and F. C. Gwazdauskas. 1999. Influence of pig substitution on milk yield, litter weights, and milk composition of machine milked sows. J. Anim. Sci. 77:1624-1630.

Guan, X., J. Pettigrew, P. Ku, N. Ames, B. Bequette, and N. Trottier. 2004. Dietary protein concentration affects plasma arteriovenous difference of amino acids across the porcine mammary gland. J. Anim. Sci. 82:2953-2963.

Hales, J., V. Moustsen, M. Nielsen, and C. Hansen. 2013. Individual physical characteristics of neonatal piglets affect preweaning survival of pig-lets born in a non-crated system. J. Anim. Sci. 91:4277-4289. doi:10.2527/jas.2013-6341.

Hansen, A., C. Lauridsen, M. Sørensen, K. B. Knudsen, and P. Theil. 2012a. Effects of nutrient supply, plasma metabolites, and nutritional status of sows during transition on performance in the next lactation. J. Anim. Sci. 90:466-480. doi:10.2527/jas.2011-3984.

Hansen, A. V., A. B. Strathe, E. Kebreab, J. France, and P. K. Theil. 2012b. Predicting milk yield and composition in lactating sows: A Bayesian approach. J. Anim. Sci. 90:2285-2298. doi:10.2527/jas.2011-4788.

Harrell, R., M. Thomas, and R. Boyd. 1993. Limitations of sow milk yield on baby pig growth. In: Proceedings of the 1993 Cornell nutrition conference for feed manufacturers, Department of Animal Science and Division of Nutritional Sciences of the New York State College of Agriculture and Life Sciences, Cornell University, Ithaca, New York. p. 156-164.

Hullar, I., and A. Brand. 1993. Nutritional factors affecting milk quality, with special regard to milk protein - A review. Acta Vet. Hung. 41:11-32.

Hurley, W. 2001. Mammary gland growth in the lactating sow. Livest. Prod. Sci. 70:149-157. doi:10.1016/S03016226(01)00208-1.

Jones, D., and T. Stahly. 1999. Impact of amino acid nutrition during lactation on body nutrient mobilization and milk nutrient output in primiparous sows. J. Anim. Sci. 77:1513-1522.

King, R. 2000. Factors that influence milk production in well-fed sows. J. Anim. Sci. 78:19-25.

King, R., and A. Dunkin. 1986a. The effect of nutrition on the reproductive performance of first-litter sows 3 . The response to graded increases in food intake during lactation. Anim. Prod. 42:119-125. doi:10.1017/S0003356100017803.

King, R., and A. Dunkin. 1986b. The effect of nutrition on the reproductive performance of first-litter sows 4 . The relative effects of energy and protein intakes during lactation on the performance of sows and their piglets. Anim. Prod. 43:319 325. doi: $10.1017 / \mathrm{S} 0003356100002506$.

King, R., M. Toner, H. Dove, C. Atwood, and W. Brown. 1993. The response of first-litter sows to dietary protein level during lactation. J. Anim. Sci. 71:2457-2463.

Klobasa, F., E. Werhahn, and J. E. Butler. 1987. Composition of sow milk during lactation. J. Anim. Sci. 64:1458-1466. 
Krogh, U., T. S. Bruun, C. Amdi, C. Flummer, J. Poulsen, and P. K. Theil. 2015. Colostrum production in sows fed different sources of fiber and fat during late gestation. Can. J. Anim. Sci. (in press). doi:10.4141/CJAS-2014-060.

Krogh, U., C. Flummer, S. K. Jensen, and P. K. Theil. 2012. Colostrum and milk production of sows is affected by dietary conjugated linoleic acid. J. Anim. Sci. 90:366-368. doi:10.2527/jas.53834.

Kusina, J., J. Pettigrew, A. Sower, M. White, B. Crooker, and M. Hathaway. 1999. Effect of protein intake during gestation and lactation on the lactational performance of primiparous sows. J. Anim. Sci. 77:931-941.

Laws, J., E. Amusquivar, A. Laws, E. Herrera, I. J. Lean, P. J. Dodds, and L. Clarke. 2009. Supplementation of sow diets with oil during gestation: Sow body condition, milk yield and milk composition. Livest. Sci. 123:88-96. doi:10.1016/j.livsci.2008.10.012.

Le Dividich, J., J. Rooke, and P. Herpin. 2005. Nutritional and immunological importance of colostrum for the new-born pig. J. Agric. Sci. 143:469-485. doi:10.1017/S0021859605005642.

Nielsen, O. L., A. R. Pedersen, and M. T. Sørensen. 2001. Relationships between piglet growth rate and mammary gland size of the sow. Livest. Prod. Sci. 67:273-279. doi:10.1016/ S0301-6226(00)00197-4.

Nielsen, T. T., N. Trottier, H. Stein, C. Bellaver, and R. Easter. 2002. The effect of litter size and day of lactation on amino acid uptake by the porcine mammary glands. J. Anim. Sci. 80:2402-2411.

Noblet, J., and M. Etienne. 1989. Estimation of sow milk nutrient output. J. Anim. Sci. 67:3352-3359.

Noblet, J., M. Etienne, and J. Dourmad. 1998. Energetic efficiency of milk production. In: M. W. A. Verstegen, P. J. Moughan, and J. W. Schrama, editors, The lactating sow. Wageningen Press, Wageningen, Netherlands. p. 113-130.

Prunier, A., C. M. Guadarrama, J. Mourot, and H. Quesnel. 2001. Influence of feed intake during pregnancy and lactation on fat body reserve mobilisation, plasma leptin and reproductive function of primiparous lactating sows. Reprod. Nutr. Dev. 41:333-348. doi:10.1051/rnd:2001135.

Quesnel, H. 2011. Colostrum production by sows: Variability of colostrum yield and immunoglobulin $\mathrm{G}$ concentrations. Animal 5:1546-1553. doi:10.1017/S175173111100070X.

Quesnel, H., C. Farmer, and N. Devillers. 2012. Colostrum intake: Influence on piglet performance and factors of variation. Livest. Sci. 146:105-114. doi:10.1016/j.livsci.2012.03.010.

Quesnel, H., F. Gondret, E. Merlot, F. Loisel, and C. Farmer. 2013. Sow influence on neonatal survival: A specific focus on colostrum. In: H. Rodriguez-Martinez, N. M. Soede, and W. L. Flowers, editors, Control of pig reproduction IX. Nottingham Univ. Press, Nottingham, UK.
Revell, D., I. Williams, B. Mullan, J. Ranford, and R. Smits. 1998. Body composition at farrowing and nutrition during lactation affect the performance of primiparous sows: I. voluntary feed intake, weight loss, and plasma metabolites. J. Anim. Sci. 76:1729-1737.

Schoenherr, W. D., T. S. Stahly, and G. L. Cromwell. 1989. The effects of dietary fat or fiber addition on yield and composition of milk from sows housed in a warm or hot environment. J. Anim. Sci. 67:482-495.

Theil, P. K. 2015. Transition feeding of sows. In: C. Farmer, editor, The gestating and lactating sow. Wageningen Academic Publishers, Wageningen, The Netherlands. p. 147-172.

Theil, P., G. Cordero, P. Henckel, L. Puggaard, N. Oksbjerg, and M. Sørensen. 2011. Effects of gestation and transition diets, piglet birth weight, and fasting time on depletion of glycogen pools in liver and 3 muscles of newborn piglets. J. Anim. Sci. 89:1805-1816. doi:10.2527/jas.2010-2856.

Theil, P. K., C. Flummer, W. L. Hurley, N. B. Kristensen, R. L. Labouriau, and M. T. Sørensen. 2014a. Mechanistic model to predict colostrum intake based on deuterium oxide dilution technique data and impact of gestation and prefarrowing diets on piglet intake and sow yield of colostrum. J. Anim. Sci. 92:5507-5519. doi:10.2527/jas.2014-7841.

Theil, P. K., C. Lauridsen, and H. Quesnel. 2014b. Neonatal piglet survival: Impact of sow nutrition around parturition on foetal glycogen deposition, and production and composition of colostrum and transient milk. Animal. 8:1021-1030. doi: $10.1017 /$ S1751731114000950.

Theil, P. K., T. T. Nielsen, N. B. Kristensen, R. Labouriau, V. Danielsen, C. Lauridsen, and K. Jakobsen. 2002. Estimation of milk production in lactating sows by determination of deuterated water turnover in three piglets per litter. Acta Agric. Scand., Sect. A 52:221-232.

Weldon, W., A. Lewis, G. Louis, J. Kovar, M. Giesemann, and P. Miller. 1994. Postpartum hypophagia in primiparous sows: I. effects of gestation feeding level on feed intake, feeding behavior, and plasma metabolite concentrations during lactation. J. Anim. Sci. 72:387-394.

Wheeler, M. B., G. T. Bleck, and S. M. Donovan. 2001. Transgenic alteration of sow milk to improve piglet growth and health. Reprod. Suppl. 58:313-324.

Wu, G., and D. A. Knabe. 1994. Free and protein-bound amino acids in sow's colostrum and milk. J. Nutr. 124:415-424. 
